Research Report No. 49/2009

\title{
Shareholder Revolt?: The Statutory Derivative Action in China
}

Flora Xiao Huang

Follow this and additional works at: http:/ / digitalcommons.osgoode.yorku.ca/clpe

\section{Recommended Citation}

Huang, Flora Xiao, "Shareholder Revolt?: The Statutory Derivative Action in China" (2009). Comparative Research in Law \& Political Economy. Research Paper No. 49/2009.

http://digitalcommons.osgoode.yorku.ca/clpe/157 


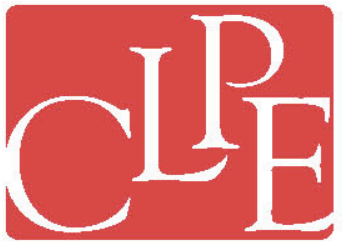

\section{Comparative Research in Law \& Political Economy}

\section{CLPE RESEARCH PAPER 49/2009}

Flora Xiao Huang

\section{Shareholder Revolt?: The Statutory Derivative Action in China}

EDITORS: Peer Zumbansen (Osgoode Hall Law School, Toronto, Director, Comparative Research in Law and Political Economy, York University), John W. Cioffi (University of California at Riverside), Nassim Nasser (Osgoode Hall Law School, Toronto, Production Editor) 

CLPE Research Paper 49/2009

Vol. 05 No. 09 (2009)

Xiao Huang

\title{
Shareholder Revolt? The Statutory Derivative ACtion in China
}

\begin{abstract}
This paper concerns one of the thorniest aspects in company law: the derivative action. As an exception to the rule in Foss v. Harbottle, individual shareholders can, acting on behalf of a company, sue the company's director if a wrong is done to the company. Private shareholders' action has been a major landscape in corporate governance in the US, but not in the UK. (Armour et al, 2007) Recently, the law on derivative action has experienced significant changes with the codification adopted in many jurisdictions. It is doubtful as to whether derivative actions are a useful mechanism to enhance investor protection.

Chinese companies have been widely conceived as having a blockholder model, in which the state as the controlling shareholder should in theory possess the incentives to constrain the opportunistic behavior of managers. Nonetheless, the state, as loosely defined as "people as a whole", has failed to exercise any effective monitoring role. The introduction of the statutory derivative action in 2005 is a significant experiment to establish an investor-friendly legal regime. However, during the transplantation of western law into China, there are several fundamental problems that need to be properly dealt with so as to allow the derivative action to function effectively.
\end{abstract}

The paper begins by examining the role of derivative actions in China, then reviews Chinese derivative action system with respect to substantive law and enforcement, and discusses the inadequacies of the present system such as costly litigation expenses and ambiguous procedures. Finally, a discussion for further reforms will inevitably include comparative references to other legal systems. The Chinese case has illustrated a paradigm shift of governance towards the role of private actors.

Key words: derivative actions, China, company law, enforcement, corporate governance JEL Classification: K22, K41, N25, O16, P37

Xiao Huang

School of Law, SOAS, University of London, United Kingdom

E-mail: 182992@soas.ac.uk 


\title{
SHAREHOLDER REVOLT? THE STATUTORY DERIVIATIVE ACTION IN CHINA
}

\author{
Xiao Huang*
}

\section{INTRODUCTION}

Minority shareholders face particular difficulties when they seek redress against wrongdoing directors because the company may not be willing to pursue this in its own right. This is particularly true when there is a fraud on the minority and the wrongdoers in control of the company. Under the Foss v. Harbottle rule in English law, the proper person to bring action is the company itself. ${ }^{1}$ Derivative action is an exception to this rule. It can be brought by individual shareholders, acting on behalf of the company, against its directors.

The common law position has been criticized for its inadequateness, such as expensive litigation expenses, personal incentives of lawyers and procedure abstains. Therefore, a number of jurisdictions like the UK and Canada have introduced the statutory derivative action. China also follows this codification trend with the adoption of derivative action in the new company law. During the transplantation of western law, the Chinese system distinguishes itself from other jurisdictions due to the underlying intrinsic market and legal institutions.

Chinese companies have been widely conceived as having a blockholder model, in which the state as the controlling shareholder should in theory possess the incentives to constrain the opportunistic behavior of managers. Nonetheless, the state, as loosely defined as "people as a whole", has failed to exercise any effective monitoring role. The introduction of the statutory derivative action in 2005 is a significant experiment to establish an investor-friendly legal regime.

This paper attempts to explore the Chinese experiment in derivative actions. The rest of the paper structures as follows. Firstly, it examines the rule in Foss v. Harbottle and the exceptions to that rule, followed by the debates over the role of derivative actions. Next, it presents a comprehensive picture of the legal framework and the judicial application of derivative actions in China. Furthermore, it examines the inadequacies of the present system, from a comparative

\footnotetext{
" $\mathrm{PhD}$ candidate in law, SOAS, University of London. This paper was presented in "Regulating a World in Crisis", Osgoode Hall Law School, York University, Toronto, May 1-2, 2009. I wish to express my thanks to Paul Jones and Gil Lan for their valuable comments.

${ }^{1}$ Foss v. Harbottle [1843] 2 Hare 461. However, this rule is arguably meaningless in the Chinese context: first, China does not belong to the common law family; second, a shareholder is indeed permitted to institute legal proceedings against company officers according to art. 153 of the Chinese Company Law.
} 
perspective, so as to explore the ways of improving derivative action. Finally, a conclusion is to be made.

\section{RULE IN FOSS V. HARBOTTLE AND ITS EXCEPTIONS}

The rule in Foss v. Harbottle has been an integral part of the company law landscape flowing from the separate legal personality between the company itself and its owners. Under the rule, the proper person to bring action is the company itself if a wrong is done to a company. It follows from two principles. The first one is "proper plaintiff" rule, which is based on the principle that a company is a legal person distinct from its shareholder and has its own legal capacity for enjoying legal rights and taking legal responsibility. ${ }^{2}$ A company can pursue an action in its own name when its interests have been damaged. ${ }^{3}$ Secondly, "majority rule principle" states that if the alleged wrong can be confirmed or ratified by a simple majority of members in a general meeting, then the court will not interfere. ${ }^{4}$

The strict application of the rule in Foss v. Harbottle would preclude a member from bringing any proceedings on behalf of a company. However, there are exceptions to the rule, which were set out by the Court of Appeal in Edwards v. Halliwell ${ }^{5}$ in the following terms:

(1) where the alleged wrong is ultra vires the company;

(2) where the transaction complained of could be validly done or sanctioned only by a special resolution and could not, therefore, be sanctioned by a simple majority;

(3) where personal rights of members are infringed; and

(4) where what is complained of amounts to fraud and those responsible for the fraud are in control of the company.

The common law derivation has been criticized as being "complex and arcane", 6 and as an accumulation of procedural "codswallop". ${ }^{7}$ Consequently, in the UK as birthplace of the rule in Foss v. Harbottle, in 1997 the Law Commission recommended the introduction of a new statutory derivative procedure "with more modern, flexible and accessible criteria for determining whether a shareholder can pursue" and action on behalf of a company. ${ }^{8}$ Chapter 1 of

\footnotetext{
${ }^{2}$ Salomon v. Salomon \& Co [1897] AC 22 at 29.

${ }^{3}$ R. Dick, "A Reconsideration of the 'Justice' Exception to the Rule in Foss v. Harbottle" (1964) 2 U.B.C. L. Rev. 547 at 548-549.

${ }^{4}$ Burland v. Earle [1902] AC 83 at 93.

${ }^{5}$ Edwards v. Halliwell [1950] 2 All ER 1064.

${ }^{6}$ S. Watkins, "The Common Law Derivative Action: an Outmodel Relic?" (1999) 30 Cambrian L. Rev. 40.

${ }^{7}$ L.S. Sealy, "Foss v. Harbottle- a Marathon Where Nobody Wins" (1981) 40 Cambridge L. J. 29 at 32.

${ }^{8}$ Law Commission Report, Shareholders' Remedies (Law Com No 246, Cm3769, 1997), para. 6.15.
} 
Part 11 of Companies Act (CA) 2006 gives effect to that recommendation by abolishing the common law derivative actions and replacing it with a statutory claim. ${ }^{9}$

In placing the derivative action on a statutory footing, the UK is following in the footsteps of other common law jurisdictions, including New Zealand, Australia and Singapore, Hong Kong and Canada. ${ }^{10}$ In these jurisdictions, there have been essentially two reasons for the introduction of a statutory derivative claim. First, a dissatisfaction with the common law derivative action; second, a desire to enable derivative claims to operate as a more effective tool of corporate governance. $^{11}$

\section{DERIVATIVE ACTIONS AND CORPORATE GOVERNANCE}

Derivative actions are related to the control of corporate form. To put it simply, plaintiff shareholders theoretically act in the interests of all shareholders, thus employing a legal mechanism to address agency problems that exist between shareholders and management. This also has led many to argue whether it plays a crucial role in aligning the interests of managers and shareholders. Indeed, according to empirical evidence, private shareholders' action has been a major landscape in corporate governance in the US, but not in the UK. ${ }^{12}$

Over the past decades, academic skepticism of derivative actions had mounted because several problems emerged, such as the procedure hurdles like demand requirement, expensive litigation costs, and the fact that many cases were driven by the lawyers and that many cases were strike

\footnotetext{
${ }^{9}$ These chapters of CA 2006 came into force on 1 October 2007. By the virtue of s. 260(1) Company Act 2006, a derivative claim is defined as proceedings by a member of a company: a) in respect of a cause of action vested in the company; and b) seeking relief on behalf of the company.

${ }^{10}$ New Zealand Companies Act 1993. The Australian statutory derivative action was introduced by the Corporate Law Economic Reform Program Act 1999 and is found in ss. 236 -237 of the Corporations Law. As for Singapore, derivative actions can be found in ss 216A \& 216B Companies Act 1994 Cap 50. Part IVAA was added to the Hong Kong's Companies Ordinance (Cap 32) in 2004. As for Canada, the statutory derivative action was introduced even more earlier, in the Canadian Business Corporations Act 1975.

${ }^{11}$ A. Steinfeld et al, The Companies Act 2006 (Oxford: OUP, 2007) at 103.

${ }^{12}$ J. Armour et al, "Private Enforcement of Corporate Law: An Empirical Comparison of the US and UK" (2007) Preliminary Draft of Law and Economics Working Paper No.89: University of Texas School of Law. However, the UK derivative action has been substantially revised by the Companies Act 2006 to streamline the procedures, which allow a shareholder to pursue a derivative claim in respect of an actual or proposed act or omission involving negligence, default, breach of duty or breach of trust by a director of the company. See the UK Companies Act 2006, ss 260-269. In practice, however, it may be doubted whether this will result in any significant extension of the circumstances in which such claims may be expected. See A. Reisberg, "Derivative Claims Under the Companies Act 2006: Much Ado About Nothing?” (2008) University College London Law Research Paper No. 09-02 at 51.Available online at: SSRN <http://ssrn.com/abstract=1092629>.
} 
suits. ${ }^{13}$ Romano referred to this type of litigations as a "stopgap" measure in corporate law. ${ }^{14}$ Fischel and Brandley claimed that the derivative lawsuits were frivolous and motivated by the settlement fees that the lawyers hope for. ${ }^{15}$ American legislature and courts also seem to take the approach that the function of derivation actions is a doubtful one. As a result, more restrictions have been placed on it. The American Law Institute (ALI), although did not wholly agree with the empirical studies and considered it difficult to make an overall evaluation of derivative lawsuits, did regard it as "neither the initial nor the primary protection for shareholders against managerial misconduct". 16

By contrast, proponents called derivative actions "the chief regulator of corporate management". ${ }^{17}$ They refuted the argument of strike suit and pointed out that the frequency of this type of suits remained an open question simply because doing so would destroy defendants' reputation. ${ }^{18}$ Furthermore, Ferris and colleagues documented 215 derivative suits in the US and found that they had been associated with significant improvements in corporate governance. ${ }^{19} \mathrm{~A}$ study by Thompson and Thomas provided that the deterrence of corporate wrongdoing was a major benefit that came out of derivative suits. ${ }^{20}$

\section{THE NEED FOR DERIVATIVE ACTIONS IN CHINA}

Although theoretical debates remain largely inconclusive, the issue of derivative actions cannot be insolated from a jurisdiction where they operate. In the Chinese context, derivative actions have three major appeals to China.

First of all, a large amount of individual investors put investor legal protection on agenda. Since the stock exchanges in Shanghai and Shenzhen were established in the early 1990s, the role of

\footnotetext{
${ }^{13}$ For a summary, see F. Wood, Survey and Report Regarding Derivative Suits (New York: Chamber of Commerce of the State of New York, 1944).

${ }^{14}$ R. Romano, "The Shareholder Suit: Litigation Without Foundation" (1991) 7:1 Journal of Law, Economics \& Organization 55 at 55.

${ }^{15}$ D.R. Fishel and M. Bradley, "The Role of Liability Rules and the Derivative Suit in Corporate Law: a Theoretical and Empirical Analysis" (1986) 71 Cornell L. Rev. 261 at 273-274.

${ }^{16}$ ALI, "Principles of Corporate Governance: Analysis and Recommendations" (1992), Part VII, Chapter 1, Introductory Note at 5.

${ }^{17}$ Cohen v. Beneficial Industrial Corp [1949] 337 US 541 at 548.

${ }^{18}$ J. Macey and G. Miller, "The Plaintiffs' Attorney's Role in Class and Derivative Litigation: Economic Analysis and Recommendations for Reform" (1991) 58 University of Chicago L. Rev. 1 at 78.

${ }^{19}$ S.P. Ferris et al, "Derivative Lawsuits as a Corporate Governance Mechanism: Empirical Evidence on Board Changes Surrounding Filings" (2001) CORI Working Paper at 25. Available online at SSRN $<$ http://ssrn.com/abstract $=495583>$.

${ }^{20}$ R.B. Thompson and R.S. Thomas, "The Public and Private Faces of Derivative Lawsuits" (2004) 57:5 Vanderbilt L. Rev. 1747 at 1775 .
} 
the stock market in China has been to raise huge amounts of capital for Chinese companies. By April 2009, there were a total of 1,625 listed companies in China's capital market with capitalization of RMB16.9 trillion. ${ }^{21}$ Currently, the Shanghai Stock Exchange ranks the fifth globally in term of market capitalization. ${ }^{22}$

What is most striking about Chinese capital markets is the dominance of small retail investors. The number of investor accounts increased from 8.35 million in 1992 to nearly 138 million by the end of $2007 .{ }^{23}$ However, small investors with less than RMB1 million in cash or shares equivalent accounted for about $99 \%$ of the total number of accounts. ${ }^{24}$ The majority of them were low-or-middle income, and 55.63\% had an annual income below RMB20, 000 in $2002 .{ }^{25}$ Meanwhile, all investors tended to have relatively short investing periods with frequent trading pattern. The average turnover ratio in China's stock market was nearly seven times higher than those in more mature markets. ${ }^{26}$

Faced with booming capital markets packed with unsophisticated individual investors, China's securities regulators have faced tough questions about the adequacy of shareholder protection. The regulatory body adopted policies based on La Porta's thesis on the positive linkage between capital market development and shareholder protection. ${ }^{27}$ As stated by Meilun Shi, former vicechairperson of the China Securities Regulatory Commission (CSRC), investor confidence and participation are critical to the healthy and stable development of China's capital markets. ${ }^{28}$ Since 2000, investor protection has consistently been the top priority of the CSRC.

Moreover, the problems of corporate governance also call for the derivative action. Indeed, a number of corporate governance measures are not as effective as expected in practice. First, a distinct feature of Chinese securities markets is that two-thirds of all the outstanding shares in

\footnotetext{
${ }^{21}$ Data from the CSRC's website. Available online at: CSRC $<$ http://www.csrc.gov.cn/n575458/n4239016/n7828263/n11147943/n11200641/11201868.html>.

${ }^{22}$ World top stock exchanges, in terms of domestic market capitalization, are in the order (as of May 2009): New York Stock Exchange, Tokyo Stock Exchange, Nasdaq, Euronext, Shanghai Stock Exchange, London Stock Exchange and Hong Kong Stock Exchange. Statistics available online: World Federation of Exchanges $<$ http://www.world-exchanges.org $>$.

${ }^{23}$ CSRC, "Executive Summary of CSRC China Capital Market Development Report" (2008) at 3.

${ }^{24}$ CSRC, China Capital Markets Development Report (Beijing: China Financial Publishing House, 2008$)$ at 269.

${ }^{25}$ B. Chen et al, "Zhongguo Gushi GerenTouzizhe Zhuangkuang Diaocha" (2002) (An Investigative Report on the Situation of Individual Investors in China's Securities Markets), Shenzhen Zhenquan Jiaoyisuo Zonghui Yanjiusuo (Research Institute of the Shenzhen Stock Exchange) Paper No.0055/2002.

${ }^{26}$ CSRC, supra note 24 at 271-272.

27. See generally R. La Porta et al, "Legal Determinants of External Finance” (1997) 52 J. Fin. 1131, R. La Porta et al, "Law and Finance" (1998) 106 J. Pol. Econ. 1113 and also R. La Porta et al, "Investor Protection and Corporate Governance" (2000) 58 J. Fin. Econ. 3.

${ }^{28}$ For details, see a speech of "Touzizhe Jiaoyu shi Jianguan Gongzuo Zhongyao Neirong” (Investor Education is an Important Component of Regulatory Work) by Meilun Shi, the then vice-chairperson of the CSRC at National Investor Education Conference on 20 July 2001. Available online at: China Central Television $<$ http://www.cctv.com/lm/266/-1/24399.html $>$.
} 
most listed companies are non-tradable, state-owned shares. Although there has been a nontradable share reform since 2005, the success of the reform remains doubtful. For the largest 30 companies in China, the overall percentage of tradable shares was only $28 \%$ in August $2008 .^{29}$ For some of them, the percentage could be below 10\%. Minority shareholders in Chinese listed companies, in the face of expropriation by the state-controlled majority shareholders, have been invariably powerless. Second, although China has been putting efforts to encourage the practice of independent directors on the board, their independence and effectiveness have been subject to criticisms.

In addition, another important reason why derivative action may have a promising prospect in China lies in the shareholder remedy regime itself. In many common law jurisdictions, there is a statutory oppression remedy for shareholders who may pursue a personal action for relief either against the company or those responsible for the "oppression", "disregard of interests", "unfair discrimination" or "prejudice". ${ }^{30}$ Disgruntled shareholders are much more likely to pursue the oppressive claims rather than the derivative action, because of a wider range of judicial remedies and relatively loose procedural requirements. ${ }^{31}$ However, since there is no such thing as the oppression remedy in China yet, the Chinese derivative action can be expected to play a more important role than its counterparts.

\section{THE LEGAL FRAMEWORK OF CHINESE DERIVATIVE ACTIONS}

\section{A. The Chinese Company LaW}

One common view is that the law did not authorize any derivative actions prior to the Chinese Company Law 2005 (CCL). The Company Law 1993 barely played any role in preventing misconduct by the controlling shareholders and directors and in protecting minority shareholders. ${ }^{32}$ Article 111 was the only provision within the Company Law 1993 granted shareholders the rights to initiate action against corporate misconduct. It provided that:

\footnotetext{
29 “30 Jia Dashizhi Gongsi jin Sancheng Xianshou Gu yi Liutong” (30 Percent of Shares in the Largest 30 Companies are Tradable), Zhengquan Ribao (China Securities Daily) (28 August 2008).

${ }^{30}$ For example, Singapore Companies Act, Cap 50, s 216, Canada Business Corporations Act 1985, ch. C-44, and the UK Companies Act 1985, s 459.

${ }^{31}$ H. Huang, 'The Statutory Derivative Action in China: Critical Analysis and Recommendations for Reform' (2007) 4:2 Berkeley Bus. L. J. 227 at 233-234.

${ }^{32}$ In the Company Law 1993, there were nearly no restrictions on the controlling shareholder. For example, there were no fiduciary duties, no cumulative voting, and no restriction on voting in the case of a related-party transaction.
} 
If a resolution adopted by the shareholders' general committee or the board of directors violates the relevant national statutes or administrative regulations, or infringes rights and interests of shareholders, a shareholder is entitled to bring a suit to the People's Court to enjoin such illegal act or infringing act.

Although this provision clearly provided the shareholder with a private right of action, it failed to indicate whether the law directly permitted derivative lawsuits. Furthermore, this article was ineffective to protect shareholders. First, it was vague and obscure to be applied since there was no regulation regarding the applicable procedures. Also, it did not elaborate the circumstances under which an action can be initiated. Second, the remedy, which the plaintiff shareholders could acquire, was only an injunction and compensations might not be granted. ${ }^{33}$ Third, the types of defendants and actionable infringements provided for were excessively narrow. ${ }^{34}$ Since this was a typical direct action, only companies can be defendants in such an action. Therefore, senior management, controlling shareholders, or other potential wrongdoers were excluded from the scope of liability even if their illegal activities had harmed the interests of a company and its minority shareholders.

Recognizing the insufficient protection for shareholders in the Company Law 1993, for the first time, the CCL 2005 established statutory derivative lawsuits. Article 150 states that a director, a supervisor or any senior officer shall be liable for any losses of the company if he/she violates any provisions of laws, or administrative regulations, or the articles of associated of the company in performance of his/her official duties. Additionally, Article 152 provides certain procedural rules.

\section{DEFENDANTS IN DERIVATIVE ACTIONS}

Shareholders are allowed to bring derivative lawsuits against a company's directors, senior officers or supervisors, as well as a third party who infringes upon the lawful rights and interests of the company. The law does not specify that controlling shareholders may be subject to derivative suits. In most Anglo-American jurisdictions, minority shareholders may initiate derivative actions against controlling shareholders. On the face of the law, a controlling shareholder who violates the rights and interests of a Chinese company, causing losses to the company, may be subject to a derivative lawsuit pursuant to Article 152.

See X.N. Li, A Comparative Study of Shareholders' Derivative Actions: England, the United States, Germany and China (Deventer: Kluwer, 2007) at $252 \& 254$.

${ }^{33}$ Ibid. at 266.

${ }^{34}$ J. Deng, "Building an Investor-Friendly Shareholder Derivative Lawsuit System in China" (2005) 46:2 Harvard Int'1 L. J. 347 at 357-358. 


\section{STANDING TO SUE}

Article 152 distinguishes companies limited by shares (CLS) from limited liability companies (LLC). As a side note, it can be said that CLS are public companies while LLC are private companies. Any individual shareholders in CLS must hold alone or jointly more than $1 \%$ of the company's shares for at least 180 consecutive days in order to initiate a derivative action. For the latter, there is no shareholding threshold, no length of shareholding requirements, nor any requirement with respect to the timing of share acquisition.

It is rational that there should be no standing limit for LLC because the abuse of derivative action in such companies is supposed to be rare. ${ }^{35}$ Eisenberg, for example, suggested that the level of mandatory regulation in corporation relations could be determined by whether the company in question is public or private. ${ }^{36}$ The logic is that, the greater the public ownership of the company, the greater the need for such legislative intervention to govern corporate relations. ${ }^{37}$ Also, shareholders in LLC are generally more powerful than those in CLS. ${ }^{38}$ Disgruntled shareholders of CLS can exit the company by selling their shares on the stock market while shareholders of the LLC do not have access to a liquid market. Even worse, a member of LLC is required to obtain the consent of a majority of other shareholders prior to a transfer of his/her shares. ${ }^{39}$ Furthermore, the proceedings and performance of CLS are already monitored by various regulatory authorities, such as the CSRC and the stock exchanges. The corporate governance of CLS is generally well guarded than that of LLC. The function of derivative action to improve corporate governance is thus more relevant to LLC.

\section{DEMAND REQUIREMENT}

According to Article 152(2), eligible shareholder plaintiffs may commence derivative suits under three alternative circumstances. The first situation is where the relevant body of the company refuses to bring an action after the receipt of written request from the shareholders. The second one is where the body has failed to bring an action within 30 days of the date of receipt of the request. The third one arises under urgent circumstances where failure to promptly institute legal proceedings could potentially cause irreparable harm to the company's interests. Thus, a

\footnotetext{
35 Thompson \& Thomas, supra note 20 at 1784-1785. Also Li, supra note 32 at 291.

${ }^{36}$ M.A. Eisenberg, "The Structure of Corporation Law" (1989) 89 Columbia L. Rev. 1461.

${ }^{37}$ However, this may not be supported by recent empirical evidence from Canada and Australia, in which the vast majority of the decisions involving the statutory derivation action have involved private companies. See I.Ramsay and B. Saunders, "Litigation by Shareholders and Directors: an Empirical Study of the Statutory Derivative Action" (2006) 6 J. Corporate L. Stud. 397 at 420.

${ }^{38}$ Huang, supra note 31 at 237.

${ }^{39}$ Chinese Company Law 2005, art. 72.
} 
shareholder wishing to bring a derivative action is required to make a demand to the board of directors to bring suit to remedy the alleged harm, or demonstrate that any delay in initiating the action would be prejudicial to the interest of the company.

Generally speaking, the demand requirement is mandated in almost all jurisdictions permitting derivative lawsuits because it provides companies with the opportunity to exhaust internal remedies first and to involve centralized management in the decision of whether to sue or not. ${ }^{40}$ It also spares the court from hearing cases which are not ripe for decision and protects companies from the harassment by frivolous shareholders in allowing the companies to reject a proposed action. $^{41}$

\section{LITIGATION EXPENSES}

The cost of litigation has traditionally been a key issue in derivative action. Shareholders in China file a suit may encounter huge financial costs that are composed of at least two parts: the court's fees and the attorney's fees. ${ }^{42}$ The court's fees include the filing fees (anjian shouli fei) paid to the court before the suit and other expenses incurred during the hearing of the case such as fees for investigation and for preservation of assets. Attorney's fees are also a financial burden on the plaintiff shareholders.

According to Article 19 of the Supreme People Court's (SPC) Measures on the People's Courts' Acceptance of Litigation Fees 1989, the losing party should bear the filing fees and other litigation fees allocated by the court excluding attorney's fees. Therefore, if the plaintiff shareholder loses the case, he has to pay a considerable amount in litigation costs. Even if he wins, he still has to pay attorney's fees and may suffer from substantial financial loss if the defendant goes bankrupt or refuses to pay him back the litigation fees. In the latter situation, he has to plea for the enforcement of judgment and then pays the filing fees for enforcement.

\section{STATUE OF LIMITATION}

A statute of limitations for derivative lawsuits is not prescribed in the CCL 2005. In this sense, this type of lawsuits is categorized into the normal civil litigation and the General Principles of the Civil Law 1986 shall apply. The applicable statute of limitations should be two years starting

\footnotetext{
${ }^{40}$ Deng, supra note 34 at 378-379.

${ }^{41}$ P. M. Choo, "The Statutory Derivative Action in Singapore: a Critical and Comparative Examination" (2001) 13 Bond L. Rev. 64 at 72-73.

${ }^{42}$ Certain under-the-table sweeteners may also have to be paid.
} 
from the date when the company knows or should know that his rights have been infringed upon. ${ }^{43}$ However, minority shareholders often do not immediately become aware of the harm done to the company. In many cases, only the managers of the company have first-hand knowledge of the occurrence of such losses. Since the managers may themselves become defendants in shareholder lawsuits, they may allow the statute of limitations to lapse without taking any legal action. Therefore, deciding the statute of limitations for shareholder derivative lawsuits based on knowledge of the company would be unfair to the plaintiff shareholders. ${ }^{44}$

\section{SETTLEMENT}

There is no special statutory guidance for settlement of a derivative lawsuit in China. Generally, settlements of civil actions in China are not subject to court approval. However, settlement without a court's supervision may cause frivolous lawsuits. Two explanations can be identified to account for this situation: first, plaintiffs' lawyers may be motivated by the prospect of receiving a percentage of the recovery amount to settle a case prematurely or to trade some of the merits of the plaintiffs' claims; second, corporate wrongdoers may be motivated to reach a settlement with plaintiff shareholders, because amounts paid in settlement may be covered by directors' and officers' liability insurance while any judgment for losses caused by management's wrongdoing is probably not. ${ }^{45}$ Therefore, courts are encouraged to play an active role in approving settlements of derivative lawsuits.

\section{B. Additional Regulations for Public Companies}

Unlike the SPC's conservative approach to the protection of minority shareholders, the CSRC has taken some more aggressive steps. It has issued several regulations with a view to improving corporate governance in public companies. These include Guidelines for Articles of Association of Listed Companies 1997; General Requirements of Shareholders' Meeting of Listed Companies 2000; Guidelines for Independent Directors to the Board of Directors of Listed Companies 2001; The Code of Corporate Governance for Listed Companies 2002 and the Regulations for the Protection of Individual Shareholders' Rights 2004.

Among these regulations, the Corporate Governance Code clearly empowers shareholders to protect their rights through legal actions. Where any decision of a shareholders' meeting or board

\footnotetext{
${ }^{43}$ General Principles of the Civil Law of the PRC, arts $135 \& 137$.

${ }^{44}$ C. Anderson et al, "Corporate Governance under the New Company Law (Part 2): Shareholders Lawsuits and Enforcement" China Law \& Practice (May 2006).

${ }^{45}$ Ibid.
} 
meeting violates the provisions of laws or administrative regulations, and infringes upon the lawful rights and interests of the shareholders, the shareholders shall have the right to institute legal proceedings for ceasing such unlawful or infringing acts according to the law. ${ }^{46}$ The directors, supervisors, or managers who, in violation of laws, administrative regulations, or the bylaws of the company, causes damages to the company shall bear the liabilities for compensation. The shareholders shall have the right to require the company to institute legal proceedings for compensation according to the law. ${ }^{47}$

\section{Judicial Application}

Although the law kept silent in relation to derivative actions, disputes between controlling shareholders and minority shareholders have not been uncommon in China since 1998. In these disputes, shareholders find it difficult to bring actions when a controlling shareholder infringes the company's interests due to a lack of legislation applicable to shareholder actions. Consequently, although many directors have been punished by either administrative sanctions or criminal prosecutions as a result of market abuse, the injured shareholders have been left without proper remedies in respect of matters of illegal actions. For example, investors in Chengdu Hongguang Industrial Co., Ltd sued the directors after an Enforcement Notice of the CSRC against Chengdu Hongguang Industrial Co in relation to Severe Breach of Regulation ${ }^{48}$ in 1998. Unfortunately, the court refused to accept the litigation due to "inappropriate plaintiff".

Similarly, Shenzhen Intermediate People's Court dismissed the appeals from an investor Mr. Zhao against the director of Sanjiu Medical \& Pharmaceutical Co., Ltd in 2003. The Court stated that a derivative action should represent the legal interests of shareholders as a whole, and the shareholders who wanted to bring derivative action must first obtain consent from all shareholders. In addition, although Mr. Li Guoguang, the deputy president of the SPC, concluded that courts should accept derivative litigation in the meeting concerning China's court adjudication work for civil and commercial affairs on 11 December 2002, the Court held the view that Mr. Li's speech could only be treated as a reference but could not be considered as the authority to establish a case. Derivative action became an acute issue in the legal enforcement of shareholders' suits and the development of securities market.

\footnotetext{
${ }^{46}$ The Code of Corporate Governance for Listed Companies 2002, art. 4.

47 Ibid.

${ }^{48}$ The CSRC published the Notice on 20 November 1998, stating that Hongguang fabricated false profits, obtained listed company statue by fraud, failed to disclose important events, and misappropriated funds. And the CSRC issued a disgorgement order and fined Hongguang and related professional intermediaries. See the CSRC's website, available online at: CSRC <http://old.csrc.goven/n575458/n575667/n642011/2006010.html>.
} 
In 2003, some High People's Courts introduced derivative action, setting up rules for trials concerning disputes among shareholders. Shanghai People's Court promulgated its Opinion on Some Issues in Trials for Legal Actions Related to Company Dispute (No 1), in which, for the first time, derivative action was introduced to China. Almost at the same time, Jiangsu High People's Court promulgated its Opinion on Some Issues in Trials for Legal Actions Applied with Company Law (Provisional Rules). It set up the rules for shareholder representative action, largely equivalent to the common law definition of derivative action.

In 2003, the SPC published the first draft of Regulations on Some Issues Concerning Trials for Company Dispute (No 1), making them open for public comments. At the end of this year, the Supreme People's Court revised the first draft based on the collected comments, and issued the second draft of its interpretation. Both drafts provide guidelines for derivative actions and are applied by each level of courts in China. According to Article 43 of the SPC Regulations, if a director, supervisor or senior officer breaches his or her obligation of loyalty to the company, or if the controlling shareholders abuse their position, thereby causing the company to incur a loss, shareholders may institute legal proceedings in their own name and the People's Courts shall accept the litigation. The SPC Draft indicates that China still plans to set highly restrictive requirements for plaintiff shareholders.

Article 44 of the SPC Regulations stipulates two prerequisites for a derivative action. First, it requires the plaintiff shareholders to meet the 'contemporaneous ownership rule', which means that they have held and continue to hold the company's shares when the conduct that infringes the company's interest occurs. Second, it requires shareholders to satisfy 'threshold requirements'. A complainant shareholder shall hold at least $10 \%$ of the equity of a limited liability company or $1 \%$ for the case of a company limited by shares. ${ }^{49}$

Meanwhile, the demand requirement for a derivative action is specified. Shareholders shall provide evidence to prove either one of the followings when initiating the action: ${ }^{50}$ a) a request to institute legal proceedings was made to the company two months ago but the company failed to act accordingly; b) there is a risk of the asset transferred, or the associated right / the time limit to bring proceedings is about to lapse; c) there are other urgent circumstances.

On April 28 2006, the SPC issued the Provisions on Several Issues concerning the Application of the PRC Company Law (Company Law Interpretations), which address certain procedural issues regarding the application of the new Company Law to civil lawsuits and clarify certain issues related to the standing requirement for shareholders who seek to initiate derivative lawsuits. Prior to the issuance of the Company Law Interpretations, the SPC announced that its interpretations of the CCL 2005 would be issued in several installments. It is possible that the SPC's

\footnotetext{
${ }^{49}$ Regulations on Some Issues Concerning Trials for Company Dispute (No 1), art. 44 (2).

${ }^{50}$ Ibid, art. 45.
} 
forthcoming interpretations will further address the vague or missing components of the derivative lawsuits procedures.

\section{MAKING DERIVATIVE ACTIONS FUNCTION}

\section{A. Litigation FeEs: InCENTIVES to COMMENCE Litigation}

As discussed earlier, litigation costs a price, which is a major obstacle in the path of a minority shareholder to take legal action against directors. A rational shareholder will normally prefer to sell his shares rather than to litigate. In financial terms, a shareholder lacks any direct remedy that would make the action worthwhile for him. Even if the litigation is successful, any damages recovered accrue to the company and the shareholder may therefore receive only a small gain. ${ }^{51}$

The treatment of fees has a direct impact on the frequency of suit. John Armour and others found that private shareholders' action has been a major landscape in corporate governance in the US, but not in the UK. ${ }^{52}$ One reason for this disparity is that procedural rules of litigation costs promote the launching of lawsuits in the US and discourage the same in Britain. ${ }^{53}$ This divergence provides a convenient basis for comparing the effect of differing treatment of fees on the decision to file a derivative suit.

Broadly speaking, there are three main ways to deal with litigation costs. Litigants in the US generally pay their own legal expenses, regardless of whether they win or lose in court. Under this system, the lawyer's fees are contingent on the case being successfully litigated or settled. Two methods are used to calculate a lawyer's fees, depending upon the form of relief awarded. If the case generates monetary relief, the lawyer's fees will be paid at a fixed percentage of the amount recovered whether by judgment or settlement. In practice, the agreed percentage is normally in the range of $20-30$ percent. $^{54}$ If a derivative action results in a substantial nonmonetary benefit to the company, the lawyer will be paid for his or her work done. The fees will be calculated on the basis of the number of hours reasonably spent on the work and the applicable market hourly rate.

\footnotetext{
${ }^{51}$ Shareholders who own small stakes in the company have little incentive to bring a derivative action because the benefit of the suit accrues to shareholders according to the size of their holding, not their efforts in bringing the action.

${ }^{52}$ Armour et al, supra note 12.

${ }^{53}$ Ibid. at 28-32.

${ }^{54}$ M. J. Loewenstein, "Shareholder Derivative Litigation and Corporate Governance” (1999) 24 Delaware J. Corporate L. 1 at 14.
} 
The UK, in contrast, has a "loser pays" regime. Rulings on costs in civil lawsuits are within the court's discretion but fees are typically assessed against the loser on a "standard basis" that covers litigation expenses "proportionately and reasonably incurred" and "proportionate and reasonable in amount". 55 "Standard basis" cost orders typically indemnify between two-thirds and four-fifths of the actual legal bills. ${ }^{56}$ A "loser pays" rule serves to deter litigation by hampering risk shifting through fee arrangements made with lawyers.

The third way is the Japanese experience. Japan's present statutory derivative action evolved from an original version that was borrowed from Germany. ${ }^{57}$ In Japan, there is a strong traditional cultural aversion to litigation as means of settling disputes. ${ }^{58}$ Indeed, litigation is seen as a "dangerous characteristic of foreigners who do not know better" 59 However, a dramatic change in Japanese law in late 1993 made it easier and cheaper for shareholders to commence derivative litigations. After the amendment to the Commercial Code, filing fees decrease from a percentage of requested damages to a fixed one JP¥8,200 (around US\$81) ${ }^{60}$ Lower the cost of suing, and more people will act.

Considering three approaches, the Japanese model is more suitable for China due to the following reasons. First, the US system of contingency fees entitles a lawyer representing a shareholder counsel fee award from the amount received by the company. In this respect, the derivative action may be driven by lawyers rather than shareholders. ${ }^{61}$ And the UK rule makes the defendant's likely legal cost relevant to the plaintiff's decision whether to sue. This will tend to deter litigation in cases where the defendant's legal fees are too high. ${ }^{62}$ By contrast, the Japanese model reduces these two possibilities and makes the derivative suit cheaper to initiate. Second, the US system does not fit neatly into the Chinese situation as the quality and quantity of

\footnotetext{
55 The UK Civil Procedure Rules, 1998, S.I. 1998/3132. para. 44.5; Lownds v. The Home Office [2002] 1 W.L.R. 2450 at 2453.

${ }^{56}$ N. Andrews, English Civil Procedure: Fundamentals of the New Civil Justice System (Oxford: OUP, 2003) at 830-831.

${ }^{57}$ Choo, supra note 41 at 92.

58 A. Williams, “Japan's Recipe for Dispute Resolution” [1996] International Commercial Litigation 2; T

L'Estrange, "Major Issues in Litigation in the Asia Pacific Rim" [1996) International Commercial Litigation 24.

59 Ibid. at 2 .

${ }^{60}$ In Japan, plaintiffs-shareholders usually lose. And filing fees, although reduced, are still more than zero. See M.D.West, "Why Shareholders Sue: The Evidence from Japan" (2000) Michigan Law and Economics Research Paper No 00-010. At the same time, it should be noted that in Japan, where the loser pays count costs, under Minsoh (Code of Civil Procedure) art. 89, if a plaintiff wins, because the damages accrue to the company, the Commercial Code, art. 268(2) provides that the company shall pay their own attorneys' fee. See further M.D. West, "The Pricing of Shareholder Derivative Actions in Japan and the United States" (1994) 88 Northwestern University L. Rev. 1436 at 1459.

${ }^{61}$ J.C. Coffee, "Understanding the Plaintiff's Attorney: The Implications of Economic Theory for Private Enforcement of Law through Class Actions" (1986) 86 Columbia L. Rev. 669.

${ }^{62}$ J.W. Hughes and E. A. Snyder, "Litigation and Settlement under the English and American Rules: Theory and Evidence" (1995) 38 J. L. \& Econ. 225 at 227-228.
} 
Chinese lawyers could not support this system. In western countries, lawyers are conceived to be professional and efficient to perform the socially useful function of deterring undesirable conduct. But in China, a sum of lawyers, coming from amateurs who are lack of experiences and skills, may find it hard to handle the complex issue of costs. Finally, concerns may be arising that the low cost would lead to frivolous derivative lawsuits. However, the derivative procedure such as the eligible plaintiff and demanding requirements can set up barriers for imprudent litigants.

\section{B. COST INDEMNITY}

The success of a derivative action depends not only on legal rights, but also on how to enforce them. Sufficient funds are, to some extent, prerequisites to those who wish to initiate proceedings when the litigation expense is high. The common law has recognized the problem of the impecunious shareholders, with the major modern development being the judgment in Wallersteiner $^{63}$ where a claimant's cost indemnity comes from the company. But the right to an indemnity cost order must be on the basis that the claimant brings the derivative action in good faith and it is in the best interest of the company. ${ }^{64}$ The question arises as to which outcome of the action could be justified as for the best interest of the company. Some remedies correct the alleged wrongdoing and get the wrong redressed from the action, while another kind of possible relief looks only to the further, ongoing protection against its recurrence. ${ }^{65}$ Another issue is that under an indemnity order the shareholder may not be compensated if the company becomes insolvent.

Despites arguments on the operation of indemnity cost orders, the rule in Wallersteiner is still reflected in many jurisdictions. In the UK, for example, the Civil Procedure Rule $200019.9 \mathrm{E}$ provides that the court may order the company for the benefit of which a derivative claim is brought to indemnify the claimant against any liability in respect of costs incurred in the permission application or in the derivative claim or both. If the claimant seeks an order that the defendant company indemnify him against liability for costs incurred in the permission application or the claim, this should be stated in the permission application or claim form or both, as the case requires.

Another example is the Canadian Business Corporation Act, Section 242 (4), providing that a court:

may at any time order the corporation or its subsidiary to pay the complainant interim costs,

\footnotetext{
${ }^{63}$ Wallersteiner v. Moir [1975] QB 373 at 389.

${ }^{64}$ In Lord Denning's words, a prima facie right of indemnification by the company arose 'on the plainest principles of equity', whether the action was successful or not. See Wallersteiner v. Moir, ibid. at 403-404.

${ }^{65} \mathrm{Q}$. Bu, "The Indemnity Order in a Derivative Action" (2006) Company Lawyer at 4.
} 
including disbursements, but the complainant may be held accountable for such interim cost on financial disposition of the application or action.

The court is allowed to exercise considerable discretion in deciding whether or not to grant costs. In Turner v. Mailhot, Reid J. held that an applicant who has obtained leave must have satisfied the conditions laid down in Wallersteiner and will therefore be prima facie entitled to an order for costs. ${ }^{66}$ It is notable that a financial need test was conducted in respect of the claimant shareholder's status. Unfortunately, the applicant finally was entitled to just half of his costs incurred to date and half of his reasonable future fees and cost.

However, there is no regulation on indemnity for the plaintiff shareholders by the company in the CCL 2005. Nevertheless, some local courts have recognized the necessity of such indemnity and have allowed it in their judicial opinion. For instance, the High People's Court of Jiangsu Province provides three alternative ways for the reimbursement of expense: ${ }^{67}$ a) prevailing shareholders should be reimbursed by the company for reasonable litigation fees such as the lawyers' fees and travel cost; b) if the court does not support the derivative claims, the litigation costs should be paid by the plaintiff shareholders; c) if the court partly support the claims, the plaintiff shareholder and the company should bear the cost pro rata. Shanghai High People's Court also promulgates guidelines where it can decide that the benefiting company should pay a reasonable indemnity to the plaintiff shareholder. ${ }^{68}$

\section{Disclosure}

One critical issue of derivative actions is disclosure. On an application for permission to continue, there is no disclosure between the claimant, the company and the wrongdoer. However, where permission is granted, the shareholder is supposed to have the right to access documents relating to the administration of the company's affairs.

The question of whether a shareholder in derivative proceedings should be entitled to early disclosure of the company's documents was concerned in the UK's Company Law Review 2000

\footnotetext{
${ }^{66}$ Turner v. Mailhot [1985] 50 O.R. (2d) 567.

${ }^{67}$ Jiangsusheng Gaojirenmin FayuanGuanyu Shenli Shiyong Gongsifa Anjian Ruogan Wenti de Yijian 'Shixing'(The Opinions of the High People's Court of Jiangsu Province on Several Issues on Adjudicating Cases Applying the Company Law 'Trial Implementation') issued on 3 June 2003, art. 78.

${ }^{68}$ Shanghai High People's Court, “Guanyu Shenli Sheji Gongsi Susong Anjian Ruogan Wenti de Chli Yijian” (The Opinions of Shanghai People's Court on Adjudicating Cases Regarding Companies Litigations (No. 1), issued on June 2003, art. 5.
} 
(CLR). ${ }^{69}$ The CLR recognized that the logic of a derivative process was that the shareholder suing in right of the company and for its direct benefit should be entitled to the information that would be available to the company. It was also recognized that a potential plaintiff should have pre-trial access to the company's papers. Nevertheless, it may encounter some obstacles in practice. The company may be able to refuse the derivative claimants' access to irrelevant documents. $^{70}$ The company also can prevent improper use of the documents by the shareholder. Furthermore, where the dispute is between a majority and a minority, a majority may take their own independent advice to retain privilege. ${ }^{71}$

Mechanisms designed to solve informational problems are adopted in many jurisdictions. Section 319 of the Australian Corporation Law 2001 provides a feasible way to enable access to documents. The court can order the applicant to inspect the company's records through a lawyer or registered company auditor acting on his behalf, on application by a shareholder, acting in a good faith and for a proper purpose. Similarly, in Germany, the right to obtain information can be exercised through a formal procedure known as the special audit. ${ }^{72}$ This means that a shareholder or a minority of shareholder can require a special audit on a particular matter to be conducted by a person, usually an auditor, who is appointed by the court for this special purpose.

By contrast, the role of the courts in China is considered as conservative regarding the shareholders' rights to obtain company information. Article 34 of the CCL empowers shareholders to review and duplicate the company's memorandum, the minutes of shareholders' meetings, the resolutions of the board of directors' meetings, the resolutions of the board of supervisors' meetings, and the financial reports. However, a shareholder who wants to review the records of the company, shall first submit a written request to it. Where the company rejects the request on the ground that this request is driven by an improper motive and may impair the interests of the company, the shareholder can plead a court to make a decision. ${ }^{73}$

In a nutshell, it is proposed that the Chinese court should make use of its jurisdiction under the CCL and allow such access in appropriate cases. ${ }^{74}$ Such a right would provide protection for shareholders, avoid misunderstandings and encourage boards to manage their companies in a

\footnotetext{
${ }^{69}$ The Company Law Review Steering Group, "Modern Company Law for a Competitive Economy: Developing the Framework" (2000) at 131-132.

${ }^{70}$ Harley Street Capital Limited v. Tchigirinsky [2005] EWHC 1897. Peter Smith J criticized the claimant for having failed to send a letter before action prior to securing a freezing order in anticipation of a derivative claim.

${ }^{71}$ D. Chivers and B. Shaw, The Law of Majority Shareholder Power: Use and Abuse (Oxford: OUP, 2008$)$ at 209.

${ }^{72}$ K.L. Hopt, "Shareholder Rights and Remedies: A View form Germany and the Continent" (1997) 2 Company Financial and Insolvency L. Rev. 261 at 264.

${ }^{73}$ The $C C L$, art. 34.

${ }^{74}$ Another way that could be followed is along the lines of a new Delaware legislation liberalizing the ability of shareholders to obtain books and records of the company "if they have a targeted, proper purpose" to see what is going on. See SB 127, 142 ${ }^{\text {nd }}$ Gen Assembly (Del 2003) (amending Del Code Ann Tit8, s.220).
} 
regular and proper manner. ${ }^{75}$ Ironically, the empirical evidence is controversial regarding the effect of whether disclosure on the likelihood of litigation. Some argue this may lead to fewer shareholder disputes being sued, ${ }^{76}$ whereas Francis and others found the opposite result. ${ }^{77}$ Time will tell whether the powers granted to the court is enough in this respect.

\section{Multiple Derivative Actions (MDAs)}

It has been a modern tendency for companies to have uncountable subsidiaries and associated undertakings. This tendency gives rise to the issue of whether a shareholder in a parent company may bring a derivative action on behalf of a subsidiary of sub-subsidiary.

Suppose that A is a minority shareholder in Company B, and that B has a wholly owned subsidiary - Company C, which in turn wholly owns Company D (that is B's sub-subsidiary). Such corporate structures offer advantages, particularly of a fiscal kind, precisely because of the respect that the courts will generally accord to the separate personality of each of the constituent companies, consistently with well-established principles of company law. How do these principles, however, affect the position of shareholder A in circumstances where wrongdoing by the directors of $\mathrm{C}$ or $\mathrm{D}$, in breach of their fiduciary or other duties to those companies, causes loss to the companies and thus indirectly to the value of his shareholding in B?

Accordingly, a claim by a shareholder in a parent company on behalf a subsidiary whose shares are held by the parent company is generally called a "double derivative action". A claim by a shareholder in the parent company on behalf of sub-subsidiary is generally called a "triple derivative action". Such actions are usually referred to by the compendious term "multiple derivative actions".

Throughout the world, there are two different attitudes to MDAs. A number of jurisdictions have already legislated to allow MDAs, such as Australia, New Zealand, Canada and Singapore. ${ }^{78}$

By contrast, some countries keep silent on the availability of such actions. For example, the UK does not have the statutory MDA. The omission stems from the fact that the Law Commission was not persuaded that it would be helpful or practicable to include such a provision in legislation. ${ }^{79}$ The Law Commission concluded that the question of MDAs was best left to the

\footnotetext{
${ }^{75}$ A. Reisberg, Derivative Actions and Corporate Governance (Oxford: OUP, 2007) at 219.

${ }^{76}$ See evidence in L. Field et al, "Does Disclosure Deter or Trigger Litigation?” (2005) 39 J. Acct. and Econ. 487.

77 J. Francis et al, "Shareholder Litigation and Corporate Disclosures" (1994) 32 J. Acct Research 137.

${ }^{78}$ See Australia's Corporations Act 2001, s 236; New Zealand's Companies Act 1993, s 165; Canada's Business Corporations Act, s 239; Singapore's Companies Act (Cap 50, Statures of Singapore, s 216A(1)(c).

${ }^{79}$ Law Commission, "Shareholder Remedies" (Law Com No 246) (1997), para. 6.110.
} 
courts to resolve, if necessary using the power under s 461(2)(c) of Companies Act 1985 to bring a derivative claim.

However common law appears to support the availability of a MDA. In the recent case of Waddington Ltd v. Chan Chun Hoo, ${ }^{80}$ where a shareholder in a parent company sought to bring a derivative claim in respect of wrongs allegedly done to several of the parent's sub-subsidiaries, the Court of Final Appeal (CFA) ruled that a MDA was maintainable. "On the well established thinking as to why a single derivative action is maintainable, there is no reason why a multiple derivative action is not." Mr Justice Bokhary PJ and Mr Justice Chan PJ agreed that. ${ }^{81}$ It is the first reasoned decision of a higher court in a common law jurisdiction outside the US to allow MDAs.

In Waddington, the question arose as to whether a shareholder of a parent company had a "legitimate interest" in a subsidiary or sub-subsidiary. On a strike out application brought by the first defendant, Barma J held that a MDA was available, at least where the shareholder could show a chain of "wrongdoer control". The CFA believed that shareholders of parent companies do have such "legitimate interest", because any depletion of a subsidiary's or sub-subsidiary's assets causes indirect loss to its parent company and therefore to its shareholders.

The CFA's judgment does not extend the statutory derivative action to MDAs. Disgruntled shareholders who wish to bring a multiple derivative action must do so via common law, whilst those wishing to bring a single derivative action are recommended to and should use Section $168 \mathrm{BC}$ of the Companies Ordinance as their basis of claim. However, the plaintiff who uses common law mechanisms cannot enjoy the statutory right to inspect the company's record, nor can they bring a claim if the alleged wrongdoing does not fall within the narrow meaning of "fraud on minority". The CFA opined in Waddington that the co-existence of the statutory derivative action and a derivative action at common law is merely a source of confusion and complication. Hence, the CFA proposed that it is appropriate for the Companies Ordinance to be amended to cover the statutory MDA as there is no justification for excluding them from the statutory scheme. $^{82}$

In the Chinese context, it is clear from the CCL 2005 that the law does not permit a member of a company to bring a multiple derivative claim. It is advisable for China to adopt the statutory MDA in the era of globalization. Giving standing to members of related companies and thereby expanding the scope of the derivative action to cover multiple aspects would provide a simple and effective mechanism for shareholders of related companies to commence a derivative claim on behalf of the companies. These measures would further enhance the protection of the interests of minority shareholders.

\footnotetext{
${ }^{80}$ Waddington Ltd v. Chan Chun Hoo Thomas and others [2008] HKLR 1381.

${ }^{81}$ Para. 2 of the CFA judgment in Waddington (FACV No. 15 of 2007).

${ }^{82} \mathrm{Ibid}$, para. 26
} 
[Vol. 05 No. 09

\section{CONCLUSION}

With the increasing number of directors' opportunistic behavior in companies, China's old company law failed to introduce derivative lawsuits as an effective shareholder relief and deterrent device to monitor corporate management. The CCL 2005 has adopted the statutory derivative action, which is a major development in Chinese company regulation and will have far-reaching implications for shareholder protection in China.

This paper has reviewed China's present system of the shareholder derivative lawsuit. The CCL and the CSRC's regulations have set up a basic legal framework to allow derivative litigations, and to some extent, made efforts to keep a balance between granting shareholders rights while simultaneously preventing frivolous suits. In practice, the SPC issued several interpretations guiding the courts how to deal with such issues. The statutory derivative action in 2005 has been a significant experiment to establish an investor-friendly legal regime.

However, during the transplantation of western law into China, there are several fundamental problems such as the fee of litigation, cost indemnity, disclosure and multiple derivative actions. These deficiencies need to be properly dealt with so as to enable the derivative action to work effectively. Hopefully, they are to be addressed by forthcoming SPC interpretations.

The open question is whether the new procedures, coupled with the new statutory statement of directors' duties, will lead to a proliferation of derivative claims. At this early stage, it is too soon to say for certain whether the new legislation will have this effect. 